\title{
Donald Trump and Difficult Relations with Europe
}

Donald Trump's presidency has turned out to pose an enormous challenge to USEuropean relations. It is difficult to escape the impression that this administration is unpredictable, its operations are dominated by chaos and emotions, and lack a thorough concept and vision, especially in the international arena. The dignity of the US Presidential Office, and that of the leader of the West, has not been augmented by Trump's governance style and by foreign policy exercised via his tweets. The development and implementation of a coherent external strategy has not been facilitated by reshuffling in the circle of Trump's closest associates and higher officials in his administration who were responsible for foreign policy and security. These personnel changes evidenced not so much a lack of skills in selecting a competent team, but rather the emotional and whimsical attitude of the incumbent President to his coworkers. Although there are also positive signals, one can talk about a crisis in a number of fields, in particular in relations with Europe.

First and foremost, some concerns and doubts which emerged with respect to the Republican candidate during the election campaign have been confirmed. It was during this campaign that Trump questioned many important tenets of transatlantic cooperation. First and foremost, he questioned the importance of NATO claiming that this is an "obsolete" structure ("The New York Times," 2016). Never before had any important US politician, let alone the President, or an important candidate for the highest office in the United States, undermined the value of NATO in such a way, as they all appreciated the importance of the North Atlantic Pact also for US interests.

Trump was also extremely unrelenting with respect to the uneven burden sharing by the allies under their joint security policy. This issue is far from new, and was addressed also by previous administrations. Yet the suggestions had not been as clear before: "The countries we are defending must pay for the cost of this defense - and, if not, the U.S. must be prepared to let these countries defend themselves" (Trump, 2016). Article 5 of the Washington Treaty assumes unconditional solidarity in the case of any NATO member state being attacked, therefore such statements issued by Trump undermined the essence of NATO, questioning the future of the North Atlantic Pact.

It appeared as if the Republican candidate for the White House did not accept or understand that the global interests and responsibilities of the United States translate into greater expenses that have to be borne, and that only the United States has an operational potential at its disposal which is unattainable for the majority of US allies in Europe. Trump seemed not to notice that NATO constitutes a powerful factor de- 
termining the US position in the international arena and that global leadership has its price and requires outlays.

Treating European obligations in the manner typical of a businessman who is concerned with profit, Trump may endanger the transatlantic community, which also cares about values and principles. He focuses on securing strictly American interests, which resembles the standards of the $19^{\text {th }}$ century global order (Wright, 2017a). This is the more dangerous, as Europe and the world in the 2010s have found themselves in an extremely difficult moment, when the existing international order is being undermined, and dangerous challenges are demanding a responsible and efficient response, not only to achieve particular narrow interests, but also to ensure security to the West, that is to the world of shared values.

The European Union, an embodiment of such a community of shared values, has become the subject of Trump's criticism as well. As a rule, US presidents used to appreciate European integration efforts, and viewed them as both the pursuit of shared values and principles and a factor which eliminated conflicts; the EU was also viewed as an important trade partner. Therefore, it is difficult to overestimate the role of the United States in stimulating the integration efforts undertaken by Western Europe in the 1950s and 1960s; also in the following decades the European project was largely appreciated in Washington.

Trump, however, starting during the election campaign, made little of the European project, which actually followed from the fact that this businessman from New York viewed the EU as an economic competitor to US interests, especially in the field of trade exchange. For this Republican candidate, an opponent of the establishment and critic of all elites, the European project symbolized the world of 'rotten liberalism' and cumbersome political correctness. When President Barack Obama visited the United Kingdom in April 2016 to persuade the British to remain in the EU, and then sent a special appeal from Germany, urging Europe to continue its integration efforts, almost at the same time Trump met the supporters of Brexit in the British Isles backing them up. He did not hide his satisfaction when the British voted for leaving the EU and called it a "great step." He joined the anti-European sentiments, strongly intensifying in different countries, and expressed his hope that further exits would follow, and the European project would cease to exist.

As an ardent supporter of trade protectionism, Trump announced a rise in tariffs and the rejection or renegotiation of international trade agreements that the United States had signed earlier (for instance, Trump called the Trans-Pacific Free Trade Partnership - TPP, signed in February 2016 "a potential disaster for our country"), therefore it should be assumed that, during his presidency, the TTIP that was being negotiated with the EU stood no chance of success.

Concerns were therefore justified that the Republican candidate, who views Europe more as a competitor than an ally, would try to weaken the EU if he won. He could, for instance, implement a policy of differentiation, whereby individual states would be 'torn away' from the European community and, through bilateral negotiations, different matters would be agreed, leading to the breakup of European unity on the one hand, and of the coherent cooperation of the United States and Europe on the other. Another deviation from Washington policy in the past concerned Trump's opinions announced 
after his electoral victory that the EU is "a vehicle for Germany," established for the purpose of efficiently competing against the United States in trade. Swiping against the strongest state in the EU, and thereby skillfully feeding anti-German sentiments in Europe, confirmed Trump's dislike for the European project and constituted an attempt to undermine its coherence.

A highly catchy element of Trump's "America First" election campaign was the message that different states sell in the United States more than they buy from it. Such trade partners were threatened to be blacklisted as "unfair trading partners." Germany and China could find themselves at the top of such a blacklist; and the German economy heavily relies on exports. Other strong accusations made against Berlin were related to the relatively low defense outlays in the German budget. It is true that the nearly $1.2 \%$ of GDP was far below the potential of the largest European economy, but the German government had made important declarations on this topic earlier. Anyway, the $1.2 \%$ of Germany's GDP accounted for USD 41 billion earmarked for defense in 2016, which is not a negligible amount. Therefore, Trump's words did not serve the prospects of American-German relations well, although they were labelled "partners in leadership" once (Kiwerska, 2017, pp. 85ff). ${ }^{1}$

Trump's electoral victory in November 2016 made this rather grim scenario a reality, both in terms of the development of US-German relations and of the whole transatlantic community. While it is true that election campaigns have their own rules, and words do not necessarily have to translate into deeds, Europe was impatiently waiting for the actual steps to be taken by the new presidential team. The first declarations were made by its representatives in February 2017, during the annual Munich Security Conference. Vice President Michael Pence did his best to sound credible when saying "on behalf of President Trump" that "the United States of America strongly supports NATO and we will be unwavering in our commitment to this transatlantic alliance" (Jones, 2017). US Secretary of Defense, Gen. James Mattis, spoke in a similar vein when he met the heads of defense of NATO member states in Brussels and declared that the Atlantic Alliance was of "fundamental" importance and that US commitments to Europe remained unchanged. The new head of the Pentagon repeated the same declaration in Munich: "The transatlantic bond remains our strongest bulwark against instability and violence. NATO exists to protect our way of life" (Mattis, 2017).

NATO members were assured that NATO's eastern flank would be strengthened. The deployment of US troops, started by the Obama administration, continued anyway, and in January 2017, 3,500 troops from the US armored brigade arrived in Poland, and a further 4,500 NATO troops were deployed in Poland, Estonia, Lithuania and Latvia by June 2017 . Washington did not send any signals that the new administration might want to withdraw from agreements made with the allies earlier, which was well received in Central and Eastern European states.

Yet the announcements by high officials in the Trump administration have not dispelled every doubt. These doubts were caused by the fact that in the US governance system final decisions are made by the President, who enjoys extremely broad competences in the field of foreign affairs. Europeans were additionally concerned with

${ }^{1}$ This was the phrase President George H. W. Bush used during his visit to Germany in May 1989, suggesting that Germany and the United States become "partners in leadership." 
Trump's unpredictability and lability, which were aptly described by Republican senator John McCain in Munich: "The president [...] makes statements and on other occasions contradicts himself" (Erlanger, 2017; Blake, 2017).

Any declaration made by Trump had to be given such a margin of uncertainty, even when he addressed Congress on February 28, 2017, and confirmed strong US support for NATO ("We strongly support NATO"). Referring to NATO as "an alliance forged through the bonds of two world wars [...] and a Cold War, and [which] defeated communism," Trump struck a familiar note present in the statements of other American presidents, who did not treat relations with Europe only in terms of a game for American interests, but also as a certain mission of America (President Trump, 2017). This was a new note in the speeches uttered by this New York billionaire, which clearly referred to values that are difficult to calculate in business accounts. The question remained whether this milder rhetoric would be sufficient to talk about a more predictable and friendly European policy of the Trump administration. Appropriate words are needed, but expectations can only be fulfilled by acts.

The US President repeated the words about the importance of NATO in April 2017 when meeting NATO Secretary General Jens Stoltenberg. The President admitted that he thought the NATO was "no longer obsolete" and that he appreciated its importance and potential (Joint press conference, 2017). This declaration eased the tension and insecurity among European allies. Nevertheless, it was utterly unthinkable that such reassurance was needed on a matter that for several decades had been imperative to US and European security, that is the US presence in Europe, and US responsibilities as the fundamental pillar of the Atlantic pillar of the Atlantic Alliance and its essential element. This was a simple outcome of Trump's earlier rhetoric, which deprecated NATO, and of insecurity about the true intentions of the new inhabitant in the White House.

President Trump consistently returned in his speeches to the demand he had made during his election campaign that NATO member states have to increase their defense budgets and "pay their fair share." He said before Congress that "our partners must meet their financial obligations" (President Trump, 2017). Vice President Michael Pence expressed a similar expectation when during the conference in Munich he reminded his listeners that, apart from the United States, only four member states meet the criterion of $2 \%$ of GDP earmarked for defense. "The promise to share the burden of our defense has not been fulfilled by too many for too long, and it erodes the foundations of our alliance," he said. "The president [...] expects our allies to keep their word, to fulfill this commitment, and for most, this means, the time has come to do more" (Jones, 2017).

Whereas the new President's standpoint on NATO and its usefulness has evolved, the Trump administration remained adamant about "burden sharing." The consistency and severity of the new administration on this issue was striking. At a meeting with the heads of defense of NATO states, held in Brussels in February 2017, Defense Secretary J. Mattis conditioned the degree of US commitment to European security on member states presenting an agenda for their meeting the requirement of earmarking $2 \%$ of their respective GDPs for defense, something they had committed to at the Newport summit. The head of the Pentagon addressed his counterparts from NATO member states saying that "Americans cannot care more for your children's future security than you do" (Cooper, 2017). 
It was difficult to reject this argument, but it should be recognized that in 2016 the expenses borne by European members of the Alliance and Canada increased by a total of $3.8 \%$ which translates into nearly USD 10 billion. Given the earlier downward trend of defense expenditure in Europe, this indicator was significant. Its significance was not diminished by the fact that in 2016, the United States allocated USD 664 billion for defense, an equivalent of $3.6 \%$ of GDP, and that by virtue of President Trump's decision this budget was increased by further USD 54 billion, or $9 \%$ (Cooper, 2017).

The issue of burden sharing kept recurring at every meeting of Trump with European leaders. Not many of them paid visits to the United States in the first year of his presidency, anyway. The above-mentioned Stoltenberg was one of them. At a joint press conference with NATO Secretary General, President Trump argued that "if other countries pay their fair share instead of relying on the United States to make up the difference, we will be much more secure and our partnership will be made that much stronger" (Joint press conference, 2017).

The subject of European outlays for defense emerged also during the visit of Chancellor Angela Merkel to Washington in mid-March 2017. This issue clearly prevailed over many other addressed during the German Chancellor's visit to the White House. In a short announcement, the US President read out during their joint press conference, he stressed the fact that while NATO remains an important American alliance, other member states need to increase their financial commitment nevertheless. He said that Germany "owed vast sum" to the United States, which clearly irritated Chancellor Merkel (Herszernhorn, 2017); this matter should not be viewed in terms of the indebtedness of NATO allies in Washington, but rather as their clearly smaller defense budgets.

This first meeting of Chancellor Merkel and President Trump left the impression that the latter appreciated the role of neither Germany, nor the importance of good American-German relations. This impression could not be altered even by the President's tweet that this was a "great meeting," an expression which Trump actually repeated several days later in an interview for the "Financial Times." Contrary to President Obama, who believed Chancellor Merkel to be his best ally, and who even talked about American-German partnership (Kiwerska, 2017b, pp. 75-88), President Trump did not recognize the position of Germany as the informal European leader, with enormous economic and political potential. Or maybe Germany's leadership in the European Union was the very factor which inspired the resentment and irritation of the eccentric inhabitant of the White House.

At any rate, Merkel-Trump meeting demonstrated the enormous differences in their political styles and thinking about international situation. Chancellor Merkel decided to visit the United States, despite Trump's waspish remarks about her refugee policy, which he considered to be a "tragic mistake," and his words that he trusted her as much as he trusted Putin. Her decision demonstrated that she was ready to go to great lengths on behalf of the European community in order to maintain a strong transatlantic bond, which was important both for European security and the position of the United States. Therefore, in the presence of US President, she presented a global outlook on the international situation and stressed the importance of cooperation between America and Europe in resolving problems. This was in stark contrast with the intellectually meager statement of Trump who focused on minor problems. 
It can therefore be said that, paradoxically, Merkel came to the United States to convince the US President that Germany was a friend and not an enemy of the United States; that even in the field of economy and trade common goals need to be sought, instead of stressing competition; finally, that there is no alternative to close cooperation between America and Germany/Europe. In the past, it was not necessary to make such efforts, despite occasional, temporary crises in American-German relations, which did not stem from a lack of understanding of the importance of collaboration, but rather from different standpoints, for instance on the American military intervention in Iraq.

The attitude of President Trump to the European Union continued to raise doubts, especially in the light of the visit UK Prime Minister Theresa May, paid to Washington on January 23, 2017. She was the first foreign guest to the White House after the inauguration of Trump's presidency. The US President treated the head of the UK government, who was embarking on the process of Brexit at the time, most cordially, announcing that a free trade agreement would be signed with the United Kingdom. It was as if he was trying to reassure the British that they had been right in opting for Brexit, and encouraging other states to take the same path. This could suggest that he maintained his opinions voiced during the election campaign when he disparaged the $\mathrm{EU}$ and drew a negative picture of its future; that he continued not to treat the EU as a strategic partner, but as a trade competitor, and would implement the policy of differentiation towards EU member states. Steve Bannon, chief advisor to the White House, said openly that the United States would negotiate better conditions in bilateral trade agreements signed with individual states.

With time, President Trump abandoned his anti-EU rhetoric. He admitted in a press interview, that his expectations that Brexit would bring about further exits, leading to the collapse of the EU, had not been realized. Therefore, he said that EU leaders "have done a very good job in bringing it [the EU] back together" (Donald Trump, 2017). Yet this did not entail his appreciation for the EU project, or treating the EU as a strategic economic partner. The EU has remained a competitor for Trump, a rival even, who enjoyed too large a surplus of export over import in trade exchange with the United States.

Concerns about the direction of US foreign policy and the future of AmericanEuropean relations have remained valid. The responsibility and predictability of the new inhabitant of the White House remained doubtful. Therefore, Trump's first visit to Europe raised great expectations and hopes of dispelling misunderstandings and ambiguities. The Brussels meeting with European leaders on May 25, 2017, however, was only one stage on the first foreign journey of the new President, who visited Saudi Arabia and Israel first, thereby implying that Europe is no longer a top US ally.

European concerns about the intentions of the new administration were not dispelled at the meeting of Trump, the President of the European Council, and the President of the European Commission. The official announcement issued by Donald Tusk said that the main difference of opinions pertained to free trade and climate issues. These were also the subjects of Trump's extreme criticism during his election campaign. It turned out that his opinions had not changed, in particular those on the climate agreement signed in Paris on December 12, 2015, aiming to reduce the emission of greenhouse gases. Given that climate change was one of the EU's main concerns, Trump's skep- 
ticism about the Paris Climate Accord and his denial of the greenhouse effect were detrimental to Washington-Brussels relations. Other differences concerned Russia and its policy, which was essential for European security. Another thing that could hardly be overlooked concerned President Trump's failure to directly address the European Union in public, recognize its role and importance, and support its integration efforts, which was in contrast to what his predecessors visiting Brussels used to do.

Other issues prevailed at an informal NATO summit, which was organized in Brussels for the purpose of facilitating a meeting of NATO member states with the US President. Although Trump's address included the sentence that NATO "promoted security and peace worldwide," the matter of burden sharing was strongly back. The President stringently rebuked member states saying that the allies "owe vast sums of money for past years" and that "NATO members must finally contribute their fair share and meet their financial obligations." His words were received as arrogant and lacking understanding for many internal determinants in individual NATO member states.

It also appeared that the American President either does not appreciate, or views it as utterly obvious, that NATO had joined the coalition fighting against Islamic State (a fight some member states had participated in on an individual basis). The declaration to join this fight had been negotiated by Stoltenberg with all NATO member states as a gesture towards President Trump, who had accused the Alliance of weak involvement in combating terrorism. NATO committed itself to training and intelligence operations, and did not actually join combat, but this was an expression of the solidarity of the allies.

Europe wanted the meeting in Brussels to be a manifestation of the unity and importance of NATO, which seemed highly necessary, given Trump's earlier statements. Nothing of the sort happened, though. What is more, the meeting lacked the accent that would be the strongest manifestation possible of unconditional help offered in the case of one of the member states being attacked. Trump did not make any reference in his speech to Article 5 of the Washington Treaty. In other circumstances this could be viewed as an irrelevant oversight since the principle of 'one for all, all for one' was in force. However, since Trump questioned the obligatory character of Article 5 before, he was expected to confirm the US obligation of mutual defense. In the past, every US President had made such a declaration, including a highly unambiguous statement issued by President Obama in 2014, after the Russian aggression in Crimea and Eastern Ukraine.

It may be assumed that President Trump's lack of endorsement of Article 5 (it is unofficially said that the text drawn up for the President and approved by his Security Advisor Herbert R. McMaster included the relevant section) was not an oversight but a conscious act by the President (Glasser, 2017a). ${ }^{2}$ It is difficult to rule out that it was intended as a kind of blackmail of European allies, who should pay more if they want US protection, and if the principle of mutual defense is to be observed. The President was not deterred by exceptional circumstances - he delivered his speech at NATO's new headquarters in Brussels, standing next to a monument commemorating the terrorist attack of September 11, 2001, when Article 5 of the Washington Treaty was im-

${ }^{2}$ According to unofficial sources, the main influence was exercised by the Chief Strategist Steve Bannon and Policy Advisor Stephen Miller. 
plemented for the first, and so far only time, in the name of solidarity with the United States.

Failing to refer to Article 5 on this occasion undermined the US's trustworthiness as an ally, and that at the moment when international order was shaking. The principle of the solidarity of the allies, which had been imperative in American-European relations for nearly seventy years, ceased to be obligatory. American experts wrote for instance: "Trump's failure to endorse Article 5 may come to be one of the greatest diplomatic blunders made by an American president since World War II" (Wright, 2017b). Strobe Talbott, a member of the Clinton administration, who was involved in enlarging NATO and adapting it to the challenges of the post-Cold War era, was convinced that the "failure to say something [about Article 5] has had a very dangerous and damaging effect on the most successful military alliance in history." Now, after Trump's speech in Brussels, Talbott argued that the "Atlantic community was less safe, and less together" (Glasser, 2017b).

The issue of Russia was justifiably mentioned. Trump's undermining of Article 5 gave Russia food for thought, and could produce dangerous outcomes. The worst scenario in the case of undermined Western solidarity involved Putin obtaining broader opportunities to implement his imperial ambition. In a slightly better option, it facilitated the Kremlin's thesis that we are living in a post-Western world, where Western values and principles no longer dominate and do not determine the direction of development and transformation. In any case, Europe and American-European relations would suffer (Stelzenmüller, 2017a; Glasser, 2017).

Under such circumstances, Trump's endorsement of America's responsibility towards its allies following from Article 5, made during his visit to Warsaw on July 6, 2017, seemed to be forced, and failed to appease European concerns about future relations with the United States. It is true that President Trump said that "the United States has demonstrated not merely with words but with its actions that we stand firmly behind Article 5, the mutual defense commitment," but the very next sentence of his speech delivered in Warsaw referred to the unsatisfactory commitment of European allies to the financing of joint defense. While this speech lacked any anti-European elements, there were no words of appreciation of the EU either, as a structure which both unites states and ensures European development and stability. The impression that Trump's reluctance toward the European project continues remained.

Europe's uncertainty about the degree of US commitment to European security inspired European leaders to act. In May 2017, Chancellor Merkel uttered her famous words that "the era in which we could fully rely on others is over [...]. We Europeans truly have to take our fate into our own hands" (Merkel nach Gipfel, 2017). These new circumstances produced a Permanent Structured Cooperation Agreement (PESCO), inspired by Germany and France. Signed by twenty-five EU members in November and December 2017, it strengthened defense cooperation within the EU. In the near future, it might limit Europe's dependence on the United States in the area of security.

That it is difficult for Europe, and in particular for the leaders of the greatest European powers, to come to an understanding with President Trump could be seen at the G7 and EU leaders' summit in Sicily on May 26-27, 2017, and at the G20 meeting in Hamburg on July 7-8, 2017. Their participants sought to persuade US President 
to acknowledge that climate warming is a real problem, and not to withdraw his signature from the Paris Agreement. Just several days after the talks in Sicily, however, on June 1, 2017, Trump announced that the United States would withdraw from Paris Agreement, which he justified with American interests and concerns about ensuring workplaces for American laborers. He remained steadfast during the G20 summit. The announcement concluding this summit included the statement that the United States was withdrawing from the provisions of the Paris agreement.

The United States' pulling out of the climate agreement had tangible outcomes, both globally and in European relations. One involved the impact it would have for the climate, as the United States is the second greatest source of greenhouse gas emissions after China. Opting for its own, rather than global interests, the United States consciously stepped down from the position of a global leader in combatting the greenhouse effect; pulling out of its earlier commitments, the United States undermined its trustworthiness, in particular in view of European states, a vast majority of which are strongly committed to preventing climate change and who see the Paris Agreement as a milestone in their endeavors. The new US administration turned out to have a different outlook and to follow its own narrowly understood interest, rather than the principles and values attributed to Western liberalism, as aptly expressed in the following words: "America First means America First, and not just in America, but everywhere on the globe" (Stelzenmüller, 2017b).

At the G20 summit in Hamburg, in turn, a compromise was reached on the wording of the provision of free trade (including the maintenance of open markets and preventing protectionism). It was recognized as an enormous success that Trump, an advocate of protectionism and opponent of multilateral trade agreements, was persuaded to back these solutions, or so it seemed at the time. This was an important achievement for the EU, a promoter of the liberal economic order, and in particular for the export-oriented German economy. Therefore this success was attributed to Chancellor Merkel, who managed to win Trump's support for free trade regulations.

When, several months later, on March 9, 2018, Trump announced his intention to raise prices for steel and aluminum, this could be viewed as his breaking earlier agreements. More importantly, however, the threat of a trade war emerged in AmericanEuropean relations. Initially, the EU avoided penalty tariffs as they were primarily imposed on Chinese imports whereas negotiations with Europe were scheduled until May 1, 2018. Nevertheless, the prospect of yet another American-European conflict affecting the economic interests of European states aroused emotions which sparked the diplomatic activity of European leaders.

Firstly, the President of France, Emmanuel Macron, arrived in the United States, clearly outpacing Chancellor Merkel in the field of relations with Trump. Whereas she never established a close relationship and understanding with the incumbent US President, Macron demonstrated greater eagerness to talk to Trump. Receiving him with honors on Bastille Day on July 14, 2017, Macron earned recognition in Washington. As a consequence, he paid a state visit to the United States from April 23 to 25, 2018, which provided him with the opportunity to demonstrate close and cordial relations with Trump. Chancellor Merkel came to the United States with a working visit of several hours, on April 27, 2018. Yet the purpose of both visits was the same, namely 
to prevent the imposition of higher tariffs for the EU and pressure President Trump on the matters of international security, first and foremost on maintaining the nuclear agreement with Iran.

The Obama administration (and Russia, China, Germany, France, the United Kingdom and the EU) signed a document (Comprehensive Plan of Action - JCPOA) providing for Iran halting its nuclear program in return for sanctions being lifted, which was considered an enormous achievement in Europe. The Trump administration, however, denied its importance, arguing that it does not block the Iranian nuclear program and is actually harmful. President Trump was to make his decision on the future of the JCPOA by May 12, 2018, which was precisely the reason for Merkel's and Macron's visits. Both Berlin and Paris feared that declining the JCPOA might translate into increased tension in the Middle East, a possibly intensified nuclear arms race, and the repeated complication of Europe-Iran trade relations, which were being reinstated so painstakingly after the period of Iran's isolation on the international arena.

As concerns tariffs on imports from the EU, the two European leaders have been partially successful. The Trump administration extended the period of the EU's exemption from US tariffs by one month, until June 1, 2018, thereby enabling negotiations to continue. Trump, however, could not be persuaded about the importance of the agreement with Iran, even though Macron and Merkel suggested that the JCPOA be added with further agreements. As on May 8, 2018, President Trump announced the US decision to withdraw from the nuclear agreement with Iran, he put the entirety of the Middle East under the risk of further destabilization and undermined the transatlantic alliance as well. European states were the signatories to the agreement, alongside Russia and China, finding themselves in clear opposition to Washington. The closest and most important US allies differed from the Trump administration over such an essential matter for international situation as the future of the denuclearization process and security in the Middle East. It was a paradox that their allies on these subjects were Russia and China. It is therefore not an exaggeration to conclude that it is a difficult time for American-European relations and their future is uncertain.

\section{Bibliography}

Blake A. (2017), John McCain just systematically dismantled Donald Trump's entire worldview, "The Washington Post" of Feb. 17.

Cooper H. (2017), Defense Secretary Mattis Tells NATO Allies to Spend More, or Else, "The New York Times" of Feb. 15.

Donald Trump in his own words (2017), 2 IV, https:/www.ft.com/content/9ae777ea-17ac-11e7a53d-df09f373be87.

Erlanger S. (2017), A Worried Europe Finds Scant Reassurance on Trump's Plans, "The New York Times" of Feb. 19.

Glasser S. B. (2017b), Strobe Talbott: The Full Transcript, http:/www.politico.com/magazine/ story/2017/06/05/strobe-talbott-brookings-foreign-policy-interview-politico-215226.

Glasser S. B. (2017a), Trump national security team blindsided by NATO speech, http:/www.politico.com/magazine/story/2017/06/05/trump-nato-speech-national-security-team-215227. 
Herszenhorn D. M. (2017), NATO's top mission: Preparing for Trump, http://www.politico.eu/article/secretary-general-jens-stoltenberg-nato-top-mission-preparing-for-us-president-donaldtr-defense-counter-terrorrism/.

Joint press conference by NATO Secretary General Jens Stoltenberg and the President of the United States, Donald Trump (2017), 12.04, http://www.nato.int/cps/en/natohq/opinions_143135. htm.

Jones B. (2017), Team Trump meets Europe, 19.02, www.brookings.edu/blog/order-fromchaos/2017/02/19/team-trump-meets-europe/.

Kiwerska J. (2017b), Obama i Merkel - budowanie partnerstwa. Relacje amerykańsko-niemieckie (2009-2016), "IZ Policy Papers,” no. 19, Poznań.

Kiwerska J. (2017a), Partnerstwo w przywództwie? Stany Zjednoczone i Niemcy (1989-2016). Perspektywa polska, Poznań.

Mattis J. (2017), Speech in Monachium, https://www.defense.gov/News/Speeches/Speech-View/ Article/1087838/remarks-by-secretary-mattis-at-the-munich-security-conference-inmunich-ger-many/.

Merkel nach Gipfel mit Trump "Die Zeiten, in denen wir uns auf andere völlig verlassen konnten, sind ein Stück vorbei” (2017), SpiegelOnline, 28.05, http://www.spiegel.de/politik/ deutscland/angela-merkel-zeigt-sich-nach-g7-gipfel-enttaeuscht-von-donald-trump-a1149588.html.

President Trump Speech to Congress (2017), 28.02, https://www.whitehouse.gov/joint-address.

Stelzenmüller C. (2017a), At last: The Trump Doctrine, revealed. And it's terrifying for Europeans, https://www.brookings.edu/blog/order-from-chaos/2017/06/05/at-last-the-trump-doctrinerevealed/.

Stelzenmüller C. (2017b), Trump's abandonment of NATO in Brussels, https://www.brookings.edu/ experts/constanze-stelzenmuller/.

“The New York Times" (2016), 21.07.

Trump says NATO not obsolete, reversing campaign stance (2017), 12.04, https://www.reuters.com/ article/us-usa-trump-nato-idUSKBN17E2OK.

Trump in Center for National Interest (2016), http://nationalinterest.org/feature/trump-foreign-policy-15960.

Wright Th. (2017b), Trump remains a NATO skeptic, https://www.brookings.edu/blog/order-fromchaos/2017/06/01/trump-remains-a-nato-skeptic/.

Wright Th. (2017a), Trump takes allies back to 19th century global order, https://www.brookings. edu/blog/order-from-chaos/2017/03/21/trump-takes-allies-back-to-19th-century-globalorder/.

\section{Summary}

The paper analyzes European-American relations in the time of Donald Trump's administration. Attention is drawn to the problems that appeared between the United States and Europe as a result of the actions of the new administration in terms of fundamental issues, such as security, economic relations, trust, and attachment to the values of the West. Trump seems to be the first American President who has no recognition of integration efforts in Europe. Also the American-German relations have been disturbed although they used to be called the "partnership in leadership" and represented an important component of the transatlantic system.

Key words: Trump, USA, EU, NATO, transatlantic relations 


\section{Donald Trump i trudne relacje z Europą}

\section{Streszczenie}

W artykule poddano analizie relacje amerykańsko-europejskie w okresie urzędowania Donalda Trumpa. Zwrócono uwagę na problemy, jakie pojawiły się na linii Ameryka-Europa w efekcie działań nowej administracji, a dotyczące kwestii zasadniczych, takich jak: bezpieczeństwo, stosunki gospodarcze, wzajemne zaufanie, wiarygodność. Zachwianiu uległy także relacje amerykańsko-niemieckie, jeszcze niedawno określane „partnerstwem w przywództwie” i stanowiące ważny komponent układu transatlantyckiego. Brak uznania dla wysiłku integracyjnego Europy także nie służy dobrze wspólnocie euroatlantyckiej.

Słowa kluczowe: USA, Unia Europejska, NATO, stosunki transatlantyckie, Trump 